\title{
Indian superbug: analysis of laypress reports
}

\author{
T Jeyaseelan Senthinath ${ }^{1 *}, P$ Revathi ${ }^{2}$, R Vigneswari $^{1}$ \\ From International Conference on Prevention \& Infection Control (ICPIC 2011) \\ Geneva, Switzerland. 29 June - 2 July 2011
}

\section{Introduction / objectives}

Following the publication on New Delhi Metalo $\beta$ Lactamase (NDM) in Lancet, Indian lay press highlighted various issues related to it, during Aug-2010. The present report aim to provide the information disseminated in the press.

\section{Methods}

Lay press materials related to Indian superbug and NDM published in 2 leading newspapers were collected daily. Consensus of 3 of the 5 was considered for categorisation. Simple descriptive statistics was used for analysis.

\section{Results}

In the Newspaper The Hindu and New Indian Express, 19 and 10 items were disseminated respectively. The matters were educative remarks of professionals, community response, political interactions, pharmaceutical comments, statements of policy makers and economical aspects including Medical Tourism.

\section{Conclusion}

The lay press reports brought out the existing suboptimal status of infection control policy, misuse of antimicrobials in India and the need for surveillances. Despite extensive press reports, practitioners \& prescribers were neither bothered nor did changed their attitude.

\section{Disclosure of interest}

None declared.

${ }^{1}$ Microbiology, Chennai Medical College Hospital\& Research Centre, Trichy, India

Full list of author information is available at the end of the article
Author details

'Microbiology, Chennai Medical College Hospital\& Research Centre, Trichy, India. ${ }^{2}$ Pharmacology, Chennai Medical College Hospital\& Research Centre, Trichy, India.

Published: 29 June 2011

doi:10.1186/1753-6561-5-S6-P301

Cite this article as: Jeyaseelan Senthinath et al: Indian superbug: analysis of laypress reports. BMC Proceedings 2011 5(Suppl 6):P301.
Submit your next manuscript to BioMed Central and take full advantage of:

- Convenient online submission

- Thorough peer review

- No space constraints or color figure charges

- Immediate publication on acceptance

- Inclusion in PubMed, CAS, Scopus and Google Scholar

- Research which is freely available for redistribution

Submit your manuscript at www.biomedcentral.com/submit

\section{() Biomed Central}

\section{() Biomed Central}

(c) 2011 Jeyaseelan Senthinath et al; licensee BioMed Central Ltd. This is an open access article distributed under the terms of the Creative Commons Attribution License (http://creativecommons.org/licenses/by/2.0), which permits unrestricted use, distribution, and reproduction in any medium, provided the original work is properly cited. 